\title{
PELATIHAN MULTIMEDIA DI SMKN 3 MANADO
}

\author{
Made Krisnanda \\ Fakultas Teknik, Universitas Negeri Manado \\ jettyfkaunang@gmail.com
}

\begin{abstract}
Abstrak
Teknologi informasi dan komunikasi berkembang sangat pesat dan telah mempengaruhi berbagai macam aspek kehidupan manusia, salah satunya dalam mendukukung pengelolaan administrasi dan pelayanan kepada masyarakat. Macromedia Flash merupakan perangkat lunak pengolah media yang digunakan untuk menampilkan gambar, video, maupun memperdengarkan suara untuk kebutuhan tertentu.. Metode yang digunakan adalah pelatihan dengan pendekatan praktis-aplikatif, praktis dimana peserta mempraktekkan semua teori yang diberikan dan aplikatif karena materi-materi yang diberikan dan dipraktekkan berkaitan erat dengan tugas dan fungsi instansi terkait. Target pelaksanan Pelatihan ini yaitu: (1) Memperoleh gambaran tentang penguasaan fungsifungsi Macromedia Flash dalam proses pendidikan. (2) Memperoleh keterampilan mengenai penggunaan fungsi-fungsi Macromedia Flash dalam mempermudah penyajian data. (3) Menjadikan perangkat pelatihan lebih kreatif dan inovatif. (4) Menerapkan ilmu yang dimiliki kepada masyarakat. Luaran dari kegiatan ini adalah: (1) Peningkatan pengetahuan dan ketrampilan siswa dalam menggunakan dan memaksimalkan fungsifungsi Macromedia Flash dengan baik. (2)Harapannya, agar supaya para siswa dapat mengoptimalkan krativitasnya. Sasaran kegiatan ini adalah para siswa jurusan Teknik Komputer dan Jaringan di SMKN 3 Manado. Kegiatan ini dirasa sangat memuaskan. Dengan indikator kehadiran peserta dan antusias peserta pelatihan cukup baik. Selain itu hasil dan suasana pelatihna juga berjalan dengan baik. Pada guru sangat mendukung kegiatan pengabdian masyarakat yang dilaksanakan oleh pelaksana.
\end{abstract}

Kata Kunci: Macromedia Flash, Multimedia, Sekolah Menengah Kejuruan

\section{PENDAHULUAN}

\section{Analisis Situasi}

Seiring dengan perkembangan era globalisasi, dunia Teknologi Informasi dan Komunikasi juga berkembang dengan pesat dan pada abad 21 ini Teknologi Informasi dan Komunikasi sudah menjadi kebutuhan primer bagi banyak kalangan. Dengan menggunakan Teknologi Informasi dan Komunikasi, suatu proses dan kegiatan dapat dilakukan dengan lebih cepat, mudah dan efisien. Oleh karena itu penguasaan terhadap perangkat teknologi komunikasi perlu diajarkan pada semua tingkatan. Macromedia Flash merupakan aplikasi yang digunakan untuk melakukan desain dan membangun perangkat presentasi, publikasi, atau aplikasi lainnya yang membutuhkan ketersediaan sarana interaksi dengan penggunanya. Proyek yang dibangun dengan Flash bisa terdiri atas teks, gambar, animasi sederhana, video, atau efek-efek khusus lainnya. SMKN 3 merupakan salah satu sekolah setingkat menengah yang ada di kota Manado. Sekolah ini memiliki lima paket keahlian, yaitu perhotelan, tata boga,.kecantikan, busana dan dan teknik komputer dan jaringan (TKJ). Dalam kurikulum pembelajaran keahlian TKJ, siswa sudah mendapatkan mata pelajaran Multimedia, namun belum termasuk program Macromedia Flash. Walaupun pada 
kenyataanya Macromedia Flash merupakan perangkat lunak yang sangat fleksibel untuk digunakan.

\section{Target dan Luaran}

Target pelaksanaan Pelatihan Fungsi-fungsi Macromedia Flash di SMK Negeri 3 Manado yaitu:

a. Memperoleh gambaran tentang penguasaan fungsi-fungsi Macromedia Flash;

b. Memperoleh keterampilan dalam mengoptimalkan fungsi aplikasi Macromedia Flash;

c. Membentuk siswa yang lebih kreatif dan inovatif; dan

d. Menerapkan ilmu yang dimiliki kepada masyarakat.

Untuk memaksimalkan potensi yang dimiliki siswa SMKN 3 Manado, diperoleh berbagai bentuk luaran, yaitu:

a. Meningkatkan kemampuan dan ketrampilan siswa dalam menggunakan dan memaksimlakan fungsi-fungsi Macromedia Flash dengan baik; dan

b. Harapannya, agar supaya siswa dapat mengoptimal potensi dan kreatifitasnya dalam menggunakan multimedia.

\section{METODE PELAKSANAAN}

\section{Pelaksanaan Kegiatan}

Untuk melaksanakan kegiatan ini, maka dilaksanakan secara bermitra antara tim pelaksana yaitu dari dosen Program Studi Pendidikan Teknologi Informasi dan Komunikasi (PTIK) Fakultas Teknik
Universitas Negeri Manado dengan Pimpinan SMKN 3 Manado.

\section{Prosedur Pelaksanaan Kegiatan}

Ada 4 tahapan yang digunakan dalam pelaksanaan kegiatan yaitu perencanaan, pelaksanaan/tindakan, eva-luasi dan refleksi hasil kegiatan, dan yang terakhir pelaporan hasil kegiatan, yang penjabarannya sebagai berikut:

a. Tahap Perencanaan, dilakukan setelah dilaksanakan survey dan analisa situasi terhadap lokasi kegiatan. Kegiatan yang dilakukan pada tahapan ini adalah tim pelaksana berkomunikasi dengan kepala sekolah SMK Negeri 3 yang akan menjadi mitra untuk membicarakan maksud dan tujuan, serta mekanisme pelaksanaan kegiatan ini. Selain itu juga membicarakan hal-hal teknis mengenai pelaksanaan kegiatan. Setelah mengkoordinasikan pelaksanaan kegiatan maka tim pelaksana menyusun program pelatihan atau workshop. Selain itu pada tahapan ini dilakukan pengumpulan alat dan bahan yang akan digunakan.

b. Pelaksanaan Pelatihan, sebelum pelaksanaan kegiatan inti dilakukan, maka dilakukan persiapan terlebih dahulu yaitu pengecekan kembali seluruh peralatan yang akan digunakan serta melakukan diskusi singkat terkait materi yang akan disampaikan. Pelaksanaan pelatihan atau workshop dikerjakan sesuai dengan program yang telah dibuat. Pelatihan atau workshop yang 
dimaksudkan direncanakan akan diadakan dalam 3 bagian, yaitu: 1) Pengenalan aplikasi Macromedia Flash secara umum; 2) Pembahasan fungsifungsi Macromedia Flash yang berhubungan minat siswa; dan 3) Mengintegrasikan fungsi-fungsi Macromedia Flash dengan minat dan potensi siswa. Untuk melaksanakan kegiatan tersebut digunakan beberapa metode pelatihan.

c. Evaluasi dan Refleksi, terhadap peserta, sehingga dapat diketahui sejauh mana pemahaman peserta terhadap apa yang diberikan. Evaluasi juga dilakukan terhadap tingkat pemahaman peserta secara teori dan praktek. Refleksi dilakukan terhadap sejauhmana tingkat keberhasilan kegiatan yang telah dilaksanakan. Selain itu juga bertujuan untuk mengetahui kekurangan dan kelebihan dari kegiatan-kegiatan yang telah dilaksanakan dalam rangka untuk menetapkan rekomendasi terhadap keberlangsungan atau pengembangan kegiatankegiatan berikutnya. Dengan kata lain ada tindak lanjut program yang sama.

d. Pelaporan Hasil Kegiatan, dibuat dari hasil kegiatan yang telah dilaksanakan sebagai bukti pertanggungjawaban terhadap instansi yang menugaskan, bahwa kegiatan telah dilaksanakan.

\section{HASIL DAN PEMBAHASAN}

Pelaksanaan kegiatan ini diawali dengan menyusun beberapa alternatif pemecahan masalah. Ada beberapa alterna- tif yang dapat dilakukan dalam memecahkan permasalahan yang dihadapi, yaitu:

a. Kepala Program Studi Teknik Komputer dan Jaringan mewajibkan siswa untuk menguasai Macromedia Flash sebagai sebuah piranti multimedia.

b. Para siswa diberikan kursus dan pelatihan singkat mengenai bagaimana membuat sebuah karya multimedia menggunakan Macromedia Flash.

Pada dasarnya semua alternatif tersebut di atas dapat ditempuh, tetapi bila dipertimbangkan lebih jauh dari berbagai segi, seperti kesiapan para perangkat, dana yang dapat disediakan, motivasi dari para siswa itu sendiri dan lain-lain, maka alternatif yang kedua dirasa lebih tepat untuk dipilih dan dilaksanakan, terutama dalam jangka pendek karena yang dikehendaki adalah perubahan yang segera diwujudkan. Bila alternatif pertama yang dipilih, persoalannya adalah apakah para guru memiliki pengetahuan dasar tentang Macromedia Flash, apakah fasilitas untuk menguasai Microsoft Flash telah tersedia dengan baik, apakah wawasan dan motivasi yang kini dimiliki memadai, dan apakah komputer di SMKN 3 itu sendiri memiliki sarana dan dana penunjang untuk itu?. Berdasarkan pertimbangan-pertimbangan tersebut, maka alternatif ketigat dipandang lebih tepat untuk dipilih, dengan beberapa alasan sebagai berikut :

a. Para siswa dapat menggunakan jam belajar dengan Mata Pelajaran yang sama; 
b. Untuk kebutuhan pelatihan, para siswa tidak perlu mengeluarkan biaya pelatihan, malah mendapatkan bantuan seperlunya untuk bahan-bahan yang diperlukan;

c. Adanya lembaga pendidikan yang sanggup melaksanakan kegiatan ini (Program Studi PTIK Fakultas Teknik UNIMA) yang memiliki tenaga profesional dalam bidangnya; dan

d. Dari percakapan dengan Kepala Sekolah SMKN 3 Manado sebelum dilaksanakan pelatihan ini, menunjukkan bahwa pihak sekolah sangat tertarik dan berkeinginan untuk melaksanakan pelatihan ini.

Jadi pemecahan masalahnya adalah dengan melaksanakan pelatihan dan kursus singkat secara langsung di lokasi atau wilayah yang menjadi sasaran kegiatan ini. Cara ini dimaksudkan untuk mengubah kondisi yang ada sekarang ini kepada kondisi yang diharapkan yaitu adanya perluasan pengetahuan, keterampilan, motivasi, kreativitas serta inovatif yang memungkinkan perangkat dapat memaksimalkan penggunaan aplikasi Macromedia Flash secara tepat dan benar.

Tabel 1. Pemecahan Masalah

\begin{tabular}{|c|c|c|}
\hline KONDISI YANG ADA & PELATIHAN SINGKAT & $\begin{array}{c}\text { KONDISI YANG } \\
\text { DIHARAPKAN }\end{array}$ \\
\hline $\begin{array}{l}\text { Siswa belum mengua- } \\
\text { sai perangkat lunak } \\
\text { Macromedia Flash, se- } \\
\text { hingga membatasi pe- } \\
\text { ngetahuan dan potensi } \\
\text { siswa dalam belajar. }\end{array}$ & $\begin{array}{l}\text { Faktor-faktor penunjang: } \\
\text { - } \quad \text { Adanya dosen Unima yang } \\
\text { profesional yang siap melak-sanakan } \\
\text { pelatihan } \\
\text { Tingginya antusias siswa dan guru } \\
\text { untuk mengikuti pelatihan singkat ini } \\
\text { - Adanya sambutan yang baik dari } \\
\text { pihak sekolah. } \\
\text { Faktor-faktor penghambat: } \\
\text { - Keterbatasan waktu, baik pada pihak } \\
\text { pelaksana (Dosen Unima), maupun } \\
\text { pihak peserta } \\
\text { Belum maksimalnya fasilitas yang } \\
\text { menunjang pelaksanaan kegiatan } \\
\text { pelatihan } \\
\text { Sulit mendapat fasilitas dalam jumlah } \\
\text { yang cukup ba-nyak secara gratis } \\
\text { untuk digunakan dalam pelatihan ini }\end{array}$ & $\begin{array}{l}\text { Adanya perluasan pe- } \\
\text { ngetahuan, keterampi- } \\
\text { lan, motivasi, kreativitas } \\
\text { serta inovatif yang me- } \\
\text { mungkinkan peserta da- } \\
\text { pat memaksimalkan } \\
\text { penggunaan aplikasi } \\
\text { Macromedia Flash } \\
\text { secara tepat dan benar. }\end{array}$ \\
\hline
\end{tabular}

Dengan memanfaatkan faktor-faktor penunjang yang ada, serta mengendalikan faktor-faktor penghambat seperti digambarkan diatas, maka diharapkan kegiatan pelatihan ini dapat memberikan hasil yang optimal. Kegiatan pengabdian pada masyarakat ini dilaksanakan berdasarkan: a. Surat tugas dari Pimpinan Fakultas dalam hal ini Dekan Fakultas Teknik Universitas Negeri Manado; dan

b. Persetujuan lisan dari Kepala Sekolah SMKN3 Manado

Dengan dasar tersebut, kegiatan program pengabdian pada masyarakat ini, 
telah dilaksanakan mulai dari tahap persiapan, tahap pelaksanaan, sampai tahap pelaporan. Yang dilaksanakan pada tahap persiapan adalah menyiapkan tim pelaksana. Dalam pelaksanaan kegiatan ini, dosen dibantu 1 orang mahasiswa Fakultas Teknik Program Studi PTIK UNIMA.

Metode yang digunakan adalah dengan presentasi, tanya jawab, demonstrasi, pemberian tugas, dan studi kasus. Pada akhir pelaksanaan pelatihan, diberikan kesempatan kepada setiap peserta untuk memberikan tanggapan terhadap pelaksanaan pelatihan ini serta memberikan pemahaman tentang bahan pelatihan yang sudah diikuti sehingga lewat tanggapan-tanggapan tersebut dapat dijadikan bahan penilaian untuk melihat tingkat keberhasilan dari pelatihan yang sudah diberikan.

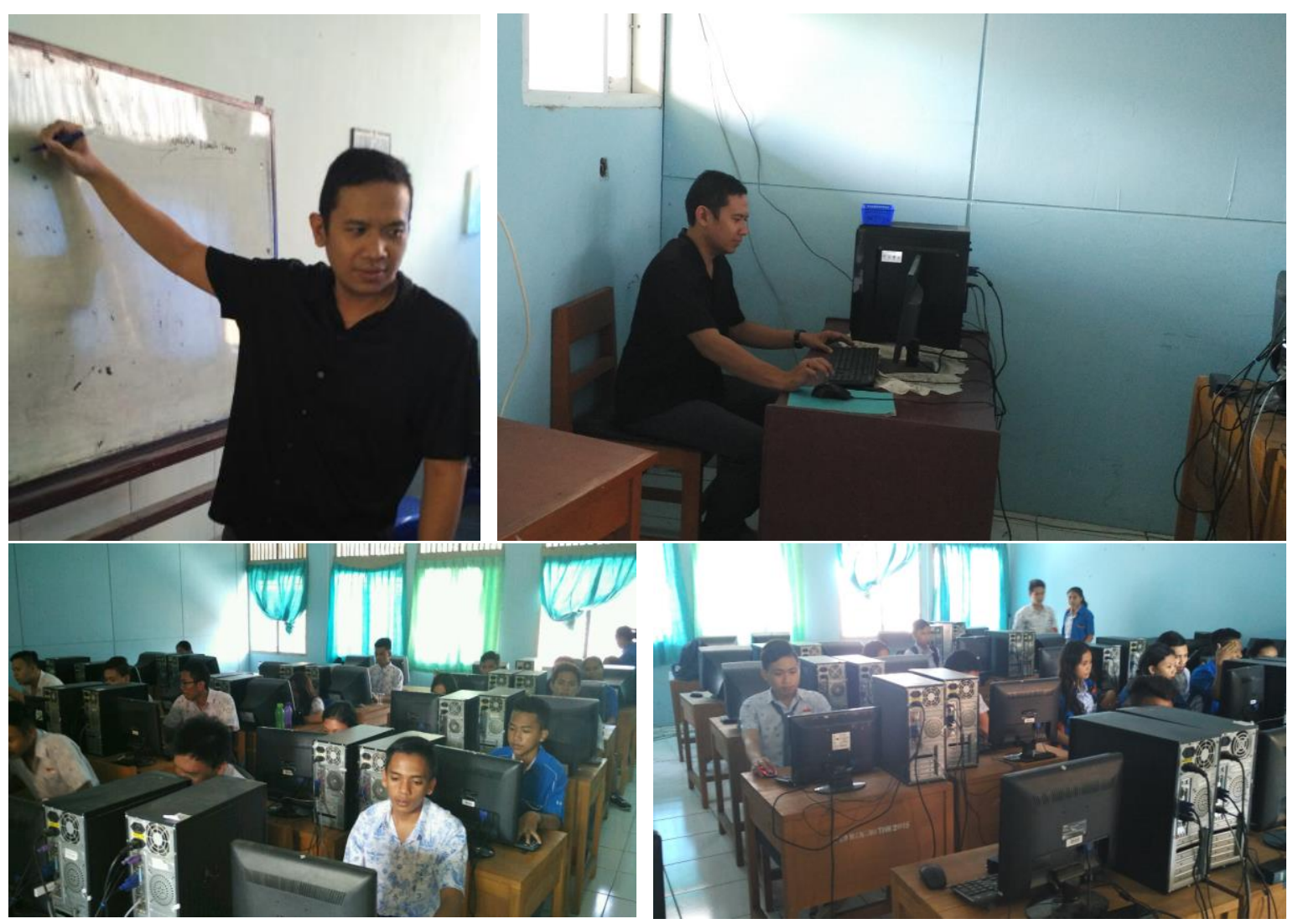

Gambar 1. Dokumentasi Kegiatan

Untuk menilai menilai sejauh mana keberhasilan pelaksanaan kegiatan program pelatihan ini, telah dilakukan evaluasi terhadap peserta. Evaluasi dilakukan selama kegiatan dengan memberikan beberapa tugas yang harus dikerjakan oleh semua peserta dan melakukan tanya jawab. Semua hasil tugas dan hasil tanya jawab dijadikan sebagai bahan penilaian keberhasilan pelatihan yang telah dilaksanakan. Seluruh hasilnya dirangkum sebagai berikut :

a. Adanya respon positif dari sekolah dan pihak terkait;

b. Peserta telah menunjukkan kesungguhan dalam mengikuti pelatihan ini 
dari awal kegiatan sampai pada akhir kegiatan;

c. Peserta sangat antusias, hal tersebut nampak jelas ketika peserta mempraktekan materi pelatihan yang diberikan;

d. Peserta menjadi lebih kreatif dan inovatif;

e. Para peserta mengakui bahwa pelatihan ini sangat perlu karena selama ini mereka hanya menggunakan fungsi-fungsi dasar Macromedia Flash yang tidak dapat secara optimal menyelesaikan masalah-masalah yang di temui;

f. Para peserta berhasil mengerjakan latihan-latihan yang diberikan;

g. Para peserta pada umumnya menyatakan bahwa mereka merasa beruntung memperoleh kesempatan mengikuti pelatihan ini, dan mereka mengharapkan Unima untuk melaksanakan kegiatan lanjutan; dan

h. Para peserta menyatakan terima kasih kepada pelaksana.

Dari penjelasan diatas, maka dapat dikemukakan beberapa hal sebagai berikut:

a. Pelatihan fungsi-fungsi Macromedia Flash bagi SMK Negeri 3 Manado yang walaupun singkat pelaksanaannya tetapi dapat mendorong tumbuhnya keterampilan, motivasi, kreativitas, serta inovatif dalam kehidupan sehari-hari;

b. Teknologi informasi dalam hal ini penggunaan Macromedia Flash sangat penting dalam menunjang pekerjaan terkait dengan pelayanan masyarakat yang prima; dan c. Program Studi PTIK Fakultas Teknik UNIMA sangat dibutuhkan diberbagai bidang guna meningkatkan kualitas berbagai bidang di Sulawesi Utara.

\section{KESIMPULAN DAN SARAN}

\section{Kesimpulan}

1) Kegiatan pengabdian masyarakat ini berbentuk pelatihan singkat fungsifungsi Macromedia Flash kepada para perangkat SMK Negeri 3 Manado telah berhasil dilaksanakan dengan baik dan mencapai tujuan yang diharapkan;

2) Kegiatan ini sebagai usaha pemerataan IPTEKS di daerah Sulawasi Utara, dimana teknologi bukan hanya diperuntukan oleh masyarakat kota besar;

3) Kegiatan ini merupakan bagian dari upaya peningkatan kualitas aparatur negara sebagai abdi masyarakat; dan

4) Kegiatan ini telah memberikan kontribusi bagi LPM UNIMA untuk mempertimbangkan dalam menetapkan program-programnya diwaktu yang akan datang.

\section{Saran}

1) Kegiatan pengabdian kepada masyarakat seperti ini perlu dilajutkan dengan materi dan kegiatan yang sama tapi dapat dilaksanakan ditempat yang berbeda, ataupun materi yang berbeda ditempat yang sama; 
2) Hubungan kerja sama antara UNIMA dengan pemerintah mulai dari pemerintah Provinsi sampai melalui Lembaga Pengabdian Masyarakat yang selama ini telah terjalin perlu ditingkatkan dan diperluas dalam menangani permasalahan yang berhubungan dengan teknologi informasi; dan

3) Setiap tenaga akademik di Perguruan Tinggi (Dosen) khusunya UNIMA hendaknya peka terhadap kondisi masyarakat serta persoalan yang ada didalamnya, dengan cara memberikan solusi-solusi yang bermanfaat dan berdampak positif.

\section{KEPUSTAKAAN}

Astuti, Dwi. 2006. Macromedia Flash 8. Yogyakarta: Penerbit Andi Diginnovac,

Arry Maulana, Karina Nasution. Draw and Animate with Flash. 2008. Jakarta: Elex Media Komputindo.

Madcoms. 2004. Macromedia Flash MX. Yogyakarta: Penerbit Andi.

Stevano, Bayu. 2006. Animasi Teks dengan Flash 8. Jakarta: Elex Media Komputindo. 
Jurnal ABDIMAS, Vol. 9, No. 1, Juni 2016 ISSN: 1979-0953 